\title{
Makna Tradisi Mepe Kasur Merah Hitam Pada Suku Bangsa Osing
}

\section{The Meaning of Drying Red-Black Mattress Tradition in Osing Tribe}

\author{
Arga Diena Prabasari \\ Departemen Antropologi, Fakultas Ilmu Sosial dan Politik, Universitas Airlangga \\ Alamat: Jalan Dharmawangsa Dalam Selatan, Surabaya, Indonesia \\ Email: argadiena@gmail.com
}

\begin{abstract}
Abstrak
Tradisi merupakan salah satu bagian dari suatu suku, tradisi dapat menjadi ciri khas dari suku tersebut. Tradisi Mepe kasur yang hanya ada di Desa Kemiren Kecamatan Glagah Kabupaten Banyuwangi. Suku Bangsa Osing di Kemiren percaya jika seorang ibu tidak memberikan kasur merah hitam kepada anak gadisnya yang akan menikah maka rumah tangganya akan kurang langgeng. Penelitian ini dilakukan dengan menggunakan metode deskriptif dengan menggunakan pendekatan kualitatif. Penelitian ini menggunakan cara pengumpulan data dengan observasi, wawancara, studi literatur, dan dokumentasi, serta dengan interpretatif budaya Clifford Geertz. Informan yang diwawancarai dalam penelitian ini berjumlah 11 orang. Hasil penelitian ini menunjukkan terdapat 5 makna dalam tradisi mepe/menjemur kasur merah hitam secara bersamaan, yaitu 1) warna merah melambangkan keberanian, 2) warna hitam sebagai simbol dari kelanggengan, 3) Kasur dengan jumlah gembil sebagai simbol sebagai status sosial pemiliknya, 4) koin sen pada kasur sebagai simbol dalam keberanian mencari nafkah, 5) kasur yang dijemur bermakna membersihkan hal-hal negatif dalam rumah.
\end{abstract}

Kata Kunci: Kasur Merah Hitam, Makna Mepe Kasur, Suku Bangsa Osing, Banyuwangi

\begin{abstract}
Tradition can be a hallmark for a tribe. The Mepe mattress tradition only exists in Kemiren Village, Glagah District, Banyuwangi Regency. The Osing tribe in Kemiren believe that if a mother does not give a red and black mattress to her daughter who is getting married, her household will not last. This research was conducted using a descriptive method using a qualitative approach. This study uses data collection methods by observation, interviews, literature studies, and documentation, as well as by interpreting Clifford Geertz's culture. Informants interviewed in this study are 11 people. The results of this study indicate that there are 5 meanings in the tradition of mepe/drying red mattresses simultaneously, which are: 1) red color as a symbol for braveness, 2) black color as a symbol of eternity, 3) Mattress with a large number of gembil as a symbol of social owner status, 4) Coinsen on the mattress as a symbol in earning for living, 5) a mattress that is dried in the sun means cleaning up negative things in the house.
\end{abstract}

Keywords: Red-Black Mattress, Interpretative of Mepe Kasur, Osing Tribe

Biokultur, 2021, 10 (2): 135-144. DOI: http://dx.doi.org/10.20473/bk.v10i2.31715

Article History:

Received November 27, 2021; Accepted November 30, 2021; Published Online December 22, 2021. 


\section{Pendahuluan}

Tradisi adalah kebiasaan yang diturunkan dari gerenasi sebelumnya yang ada dalam suatu kelompok masyarakat (Mardimin 1994 dalam Wilwatikta 2019:6). Oleh sebab itu tradisi digunakan sebagai pedoman untuk berakhlak dan bertingkah laku masyarakat, sehingga banyak tradisi yang dapat ditemui di Indonesia. Salah satunya adalah tradisi dari Suku bangsa Osing di Desa Kemiren, Kecamatan Glagah, Kabupaten Banyuwangi yang dikenal dengan tradisi Mepe/menjemur Kasur bersamaan. Fenomena ini menarik untuk diteliti lebih mendalam.

Suku bangsa Osing tidak hanya berada di Desa Kemiren tetapi juga menyebar hampir keseluruh desa yang ada di Banyuwangi. Akan tetapi, meskipun demikian budaya dan tradisi yang ada pada setiap desa yang ditinggali Suku Osing berbeda-beda. Seperti di Desa Olehsari pelaksanaan tradisi mepe Kasur diiringi tari tarian yang berbeda. Tari seblang, penarinya berusia masih muda dan perawan, selain itu di Desa Glagah terdapat gelar pitu dan weluri serba tujuh. Tradisi-tradisi yang ada ini bukanlah tradisi baru tetapi tradisi yang sudah ada sejak dahulu dan diturunkan oleh nenek moyang pada masing-masing desa.

Tradisi Mepe kasur merupakan serangkaian acara bersih desa Suku Osing di Desa Kemiren yang puncaknya adalah acara tumpeng sewu atau selametan desa sebagai wujud rasa syukur terhadap yang kuasa. Mepe kasur adalah salah satu tradisi Suku Bangsa Osing di Desa Kemiren yang dilaksanakan menjelang hari raya Idul Adha atau pada bulan Dzulhijjah. Suku Bangsa Osing secara serentak menjemur kasur mereka di depan rumah, warna kasur ini merah dan hitam yang dalam warna tersebut menyimpan sebuah makna. Kasur yang digunakan pun tidak dapat dijumpai disembarang tempat melainkan hanya dapat dijumpai di Desa Kemiren, karena kasur merah hitam hanya dibuat oleh warga asli Suku Bangsa Osing.

Dalam Penelitian Syam (2017) dari Unversitas Hasanuddin yang meneliti mengenai pergeseran makna Tradisi Kalomba bagi komunitas Kajang dalam Tanah Toa di Bolu Kumba yang berisi terkait ritual dan tradisi yang dapat memperkokoh eksistensi dari agama yang dianut oleh masyarakat. Pranata agama memiliki fungsi manifes atau nyata berkatan dengan doktrin, ritual, hingga perilku dalam beragama dan fungsi laten. Ritual ini merupakan prosesi yang diperuntukkan anak anak di Suku Kajang untuk menghilangkan sial dan penyakit dari leluhurnya. Kajian terkait memertahankan makna dan simbol dalam masyarakat yang mengalami pergeseran dari masa ke masa.

Penelitian Fuadhiyah (2011) dari Universitas Negeri Semarang dengan judul simbol dan makna kebangsaan dan lirik lagu dolanan/mainan di Jawa Tengah yang membahas mengenai salah satu seni sastra tradisional berupa lagu Dolanan dari Jawa Tengah. Penelitian ini menjelaskan mengenai lagu dolanan sebagai karya sastra yang terdapat puisi Jawa tradisional yang umunya berbentuk Tembang. Kemudian peneliti mengaitkan lagu dolanan dengan pendidikan, sebab menurut peneliti lagu dapat dijadikan sebagai aspek dalam berbangsa seperti contohnya lagu Lir ilir-ilir yang mana beberapa liriknya dapat dipahami sebagai ungkapan sikap peduli terhadap kemerdekaan bangsa Indonesia.

Penelitian oleh Winoto (2018) dari Universitas Padjajaran mengenai studi fenemenologi makna pencemaran lingkungan bagi para penambang emas tradisional di kabupaten Tasikmalaya yang 
berisi kegiatan penambang emas memberikan beberapa dampak yang negatif sebab pertambangan ini bersifat illegal atau penambangan tanpa izin yang mana sangat membahayakan keselamatan dari penambang itu sendiri dan menyebabkan kerusakan lingkungan karena pengeloaan biji emas menggunakan bahan bahan berbahaya. Kegiatan penambangan di desa Cikondang, telah menjadi budaya bagi masyarakat sekitar yang menyebabkan sulit berubah. Penambang di desa tersebut memaknai pencemaran lingkungan dengan menggunakan bahan berbahaya bukanlah hal yang merugikan, karena tidak ada keluarga yang dirugikan atau meninggal pada saat pengolahan biji emas.

Penelitian tentang makna dari tradisi Mepe kasur pada Suku Bangsa Osing di Desa Kemiren yang utama dibahas peneliti yaitu mengenai makna yang terdapat dalam Kasur Merah Hitam dan makna yang ada dalam tradisi Mepe kasur itu sendiri. Oleh karena itu, peneliti tertarik untuk memilih judul tersebut sebab rasa keingintahuan peneliti mengenai keunikan dalam memaknai tradisi Mepe kasur ini sehingga tradisi ini masih tetap ada hingga saat ini.

Teori yang digunakan dalam penelitian ini adalah teori interpretatif kebudayaan dari Clifford Geertz untuk menganalisis mengenai penamaknaan tradisi Mepe kasur di Desa Kemiren dengan menggunakan epistemologi hermeneutik dan paradigma tafsir kebudayaan dari Clifford Geertz (1992). Dalam tafsir kebudayaan (Geertz, 1992:15) mengatakan bahwa simbol dan makna memiliki sifat publik dan bukan bersifat privat atau milik perseorangan. Hal ini sesuai teori interpretasi kebudayaan "Kebudayaan bersifat publik, sebab makna bersifat publik". Melalui pernyataan tersebut kebudayaan dan makna memiliki kedudukan yang sama. Keduanya memiliki sifat yang sama yaitu publik. Makna dan kebudayaan merupakan unsur penting yang dimiliki oleh manusia.

Rumusan masalah penelitian adalah bagaimana Suku Osing di Desa Kemiren dalam memaknai tradisi Mepe Kasur? Sebab tradisi mepe kasur merupakan salah satu tradisi yang masih dipertahankan oleh Suku Osing di Desa Kemiren hingga saat ini dan tradisi ini merupakan bagian dari acara bersih di Desa Kemiren sebagai wujud rasa syukur masyarakat Kemiren kepada Sang Pencipta.

\section{Metode}

Penelitian mengenai makna tradisi mepe kasur difokuskan pada Suku Osing di Desa Kemiren, Kecamatan Glagah, Kabupaten Banyuwangi. Desa Kemiren dipilih sebab tradisi Mepe kasur berasal dan hanya dapat ditemui di desa tersebut meskipun Suku Osing menyebar di seluruh penjuru kota Banyuwangi. Menggunakan metode kualitatif untuk memperoleh jawaban dari masalah penelitian. Penelitian ini bersifat deskriptif karena tujuan penelitian ini memahami aktivitas terkait tradisi mepe kasur merah hitam, bagaimana cara membuat kasur merah hitam, bagaimana cara Suku Bangsa Osing dalam memaknai tradisi mepe kasur merah hitam di Desa Kemiren.

Manusia merupakan instrumen penting dalam metode kualitatif, karena peneliti secara langsung terjun ke lapangan dan bertatap muka dengan informan, sehingga peneliti dapat memperoleh data yang diinginkan melalui interaksi secara langsung. Selain itu, peneliti memilih metode kualitatif 
sebab pada metode ini peneliti dapat membatasi hal-hal yang sekiranya berada di luar fokus. enelitian ini menitik beratkan kepada sudut pandang masyarakat di Desa Kemiren.

Dalam memilih informan sebelumnya peneliti menentukan informan kunci (key informan) terlebih dahulu untuk mempermudah dan menjembatani peneliti dalam mencari data dari objek yang diteliti. Kemudian peneliti menggunakan teknik dari Spradley (1997:6-70) yaitu enkulturasi penuh (sangat memahami budaya mereka sendiri tanpa lama berpikir, memiliki pengalaman informal selama bertahun-tahun), keterlibatan langsung (terlibat langsung dalam kebudayaan mereka), suasana budaya yang tidak dikenal (peneliti berada diluar lingkungan objek dan awam terhadap kebudayaan objek), cukup waktu (informan yang bersangkutan memiliki cukup waktu ketika sedang dimintai informasi mengenai objek penelitian, jika tidak cukup waktu maka peneliti dapat menggunakan informan ganda yang memiliki kriteria sama dengan informan sebelumnya), dan non analitik (informan yang memberikan informasi harus apa adanya tanpa menambah atau mengurangi fakta yang ada dilapangan).

Dari teknik pemilihan informan Spradley peneliti kemudian mendapatkan 11 informan yang sesuai diantaranya adalah Ketua Adat Desa Kemiren, 3 orang warga asli Kemiren yang merupakan pembuat kasur Merah Hitam, 1 orang tokoh masyarakat, 2 orang panitia tradisi mepe kasur, 4 orang warga asli Desa Kemiren (termasuk tokoh masyarakat), kepala Desa Kemiren, serta seorang staf bidang kebudayaan Dinas Kebudayaan dan Pariwisata Kabupaten Banyuwangi.

Penelitian ini dilakukan pada bulan Juli 2019 untuk observasi, bulan Agustus 2019 hingga bulan Januari 2020 untuk turun lapangan. Dengan rincian pada tanggal 29 Juli 2019 peneliti mencari data kepada Ketua Adat di Kemiren, tanggal 7 Agustus 2019 di Rumah Budaya Osing yang masih dalam daerah Desa Kemiren, pada tanggal 17 September 2019 mencari data di Kantor Desa Kemiren, 27 Desember 2019 wawancara mendalam dengan staf bidang kebudayaan Dinas Kebudayaann dan Pariwisata Kabupaten Banyuwangi, 28 Desember 2019 mencari data di salah satu homestay milik warga, 31 Desember 2019 ke rumah salah satu informan, 10 Januari 2020 wawancara mendalam seorang anggota Kelompok Sadar Wisata/ Pokdarwis di Desa Kemiren. Pokdarwis merupakan organisasi sosial di Desa Kemiren yang anggotanya mayoritas adalah anak muda dari Desa Kemiren yang juga sebagai informan. Peneliti juga tidak lupa melakukan observasi dan wawancara mendalam dengan pembuat kasur merah hitam yaitu pada tanggal 4 Agustus 2019 dan dilanjutkan pada tanggal 10-12 Januari 2020 peneliti mencari data pada ketiga pembuat kasur merah hitam di Desa Kemiren. Waktu yang digunakan cukup lama karena untuk mengetahui proses awal dari tradisi mepe kasur yang dilakukan setahun sekali dan untuk memahami cara Suku Bangsa Osing di Desa Kemiren dalam memakna tradisi mepe kasur dan kasur Merah Hitam milik mereka.

Peneliti beruntung sebab tradisi mepe kasur yang hanya diadakan setahun sekali yaitu pada bulan haji dan pada tanggal 4 Agustus 2019 ketika peneliti sedang di lapangan, sehingga tradisi mepe kasur yang sedang dilaksanakan dapat diobservasi langsung oleh peneliti. Peneliti dapat mengetahui secara langsung dan dapat mencatat serta mengamati aktivitas proses dari tradisi mepe Kasur. Antusias Suku Bangsa Osing di Desa Kemiren melaksanakan tradisi ini sangat besar. Beberapa kali, orang yang sedang melintas berhenti karena penasaran dengan kasur Merah Hitam yang sedang dijemur secara serentak di sepanjang jalan Desa Kemiren. 
Dalam penelitian ini, guna memperoleh data diperlukan suatu teknik pengumpulan data yang terkait dengan Makna tradisi Mepe kasur pada Suku Bangsa Osing di Desa Kemiren, maka digunakan metode observasi. Metode ini dipilih karena dapat mengamati secara langsung kondisi dan keadaan ketika tradisi Mepe kasur sedang berlangsung serta cara Suku Osing dalam memaknainya. Selama observasi peneliti juga mendokumentasikan kegiatan yang sedang berlangsung sebagai data pendukung dan menunjukkan suasana ketika tradisi ini sedang berlangsung dan aktivitas ketika tradisi ini dilaksanakan. Peneliti juga sangat mudah untuk menjelaskan mengenai keadaan di Desa Kemiren. Kemudian peneliti juga menggunakan teknik wawancara untuk mendapatkan informasi yang lebih mendalam serta rinci dari Suku Osing yang ada di Desa Kemiren.Wawancara adalah suatu cara yang digunakan untuk tujuan tertentu, mencoba mendapatkan sebuah informasi dengan cara lisan dan dapat berkomunikasi secara langsung atau tatap muka kepada informan. Teknik wawancara yang digunakan adalah wawancara mendalam atau indepth interview. Agar peneliti mendapatkan data yang sebenarnya maka peneliti menjalin rapport atau melakukan pendekatan terlebih dahulu dengan informan.

Pendekatan yang dilakukan adalah dengan membaur bersama Suku Bangsa Osing di Kemiren ketika tradisi Mepe kasur sedang berlangsung dan sering mengunjungi rumah penduduk. Sebelum melakukan wawancara peneliti telah mempersiapkan dan menyusun beberapa pertanyaan terkait dengan permasalahan yang sedang diteliti. Selain observasi, wawancara, dan dokumentasi pengumpulan data juga dilakukan dengan studi literature dari jurnal dan buku yang terkait dengan masalah yang sedang diteliti. Studi Literatur juga mempermudah peneliti untuk memperkuat data yang telah diperoleh dengan beberapa sumber buku bacaan yang diperoleh diperpustakaan atau pun ejournal dan website terpercaya.

\section{Hasil Dan Pembahasan}

Secara Bahasa Mepe kasur berasal dari Bahasa Jawa yang berarti menjemur kasur, tradisi Mepe kasur merupakan kebudyaan asli Suku Bangsa Osing yang dilakukan pada saat Bulan Dzulhijjah (Bulan Haji) atau lebih dikenal dengan Hari Raya Idul Adha. Hari pelaksanaannya adalah minggu awal Idul Adha dan selalu dipilih antara hari Kamis atau hari Minggu, karena menurut masyarakat Desa Kemiren kedua hari tersebut merupakan hari yang sakral. Jarang sekali masyarakat Kemiren menggunakan hari lain untuk menggelar acara jika memang tidak urgent. Akan tetapi masyarakat di Desa Kemiren tidak mengetahui asal mula mengapa kedua hari tersebut dijadikan sebagai hari keramat atau dianggap sakral. Mereka hanya menjalankan kebiasaan dari nenek moyang atau generasi terdahulu.

Tradisi ini muncul dan dicetuskan dari musyawarah masyarakat Desa Kemiren pada tahun 2009 yang merupakan salah satu rangkaian kegiatan dari acara Tumpeng Sewu yang juga dikenal dengan bersih desa. Tradisi Mepe Kasur ini menggunakan media Kasur Merah Hitam sebagai pelaksanaannya. Pembuat atau pengrajin Kasur Merah Hitam tersebut merupakan Suku Bangsa Osing asli Kemiren. Proses pembuatan kasur tersebut tidak hanya memanfaatkan kegiatan bersih desa namun juga kegiatan lain. Kasur Merah Hitam juga diproduksi apabila ada pemesanan dari pihak tertentu.

Pembuatan kasur Merah Hitam sendiri layaknya pembuatan kasur pada umumnya. Proses pembuatan kasur merah hitam justru terbilang sangat sederhana dimulai dari pengukuran kasur, 
kemudian menjahit tepi-tepi kasur, selanjutnya memasukkan kapuk sebagai isian kasur, dan yang terakhir menjahit seluruh bagian kasur. Proses yang memakan waktu lama adalah ketika menjahit, karena memang hanya dikerjakan oleh satu orang saja dan ukuran kasur yang dipesan setiap orang berbeda-beda. Salah satu pembuat kasur merah hitam yang sudah cukup tua umurnya menjelaskan bahwa membuat kasur karena keterbatasan ekonomi keluarganya dahulu tetapi informan ingin melihat keluarganya merasakan kasur yang empuk. Pada saat itu kapuk memang masih sangat mudah ditemui di Desa Kemiren, sehingga digunakan kapuk sebagai isian untuk kasurnya yang kemudian saat itu dimasukkan dalam kain merah hitam dan dijahit dengan tangan untuk menutup sisi-sisi kasur yang terbuka.

Pesanan kasur merah hitam biasanya meningkat ketika memasuki Hari Raya Idul Adha dan mendekati acara bersih desa di Desa Kemiren, sebab banyak yang menikah di bulan tersebut. Sehingga pembuat kasur merah hitam seringkali kewalahan dengan peningkatan pesanan karena mereka membuat seorang diri. Diluar Idul Adha pembuat kasur merah hitam masih tetap mendapatkan pesanan dari masyarakat Kemiren untuk membenarkan dan mengisi kapuk yang baru pada kasur merah hitam yang mereka miiiki. Selain dari masyarakat Kemiren, peningkatan pesanan kasur merah hitam juga datang dari orang luar desa hingga luar kota yang ingin membeli kasur merah hitam untuk mereka. Peningkatan pesanan kasur merah hitam dari luar kota terjadi karena masyarakat luar kota tertarik dengan kasur merah hitam yang baru diketahui setelah acara tumpeng sewu dan tradisi Mepe kasur selesai dilaksanakan.

Pembuat kasur merah hitam tidak sepenuhnya mengetahui makna dari kasur yang mereka buat. Mereka beranggapan bahwa itu bukan ranah mereka. Akan tetapi ada pihak lain yang dapat memaknai kasur merah hitam tersebut yaitu masyarakat Desa Kemiren sendiri, karena kasur merah hitam merupakan bagian dari budaya masyarakat Kemiren, sehingga yang lebih memahami akan nilai filosofis dari kasur tersebut adalah masyarakat Kemiren. Masyarakat di Desa Kemiren tidak ingin jika warna kasur merah hitam diganti seperti kasur pada umumnya sebab kasur merah hitam merupakan warisan dari leluhur mereka, sehingga mereka akan tetap menggunakan kasur merah hitam meskipun mereka juga memiliki kasur springbed.

Sejak pagi hari yakni pukul 09.00 WIB hingga sore hari pukul 15.00 WIB, kasur merah hitam dijemur di semua dusun yang ada di Desa Kemiren yaitu Dusun Kedaleman dan Krajan yang memiliki pola memanjang mengikuti jalan raya. Masyarakat tidak hanya menjemur kasur saja melainkan juga menepuk-nepuk kasur agar debu yang ada dalam kasur merah hitam dapat hilang dan kasur menjadi bersih serta empuk kembali. Sebenarnya tidak ada aturan dari desa kapan saja kasur merah hitam harus dijemur. Mepe kasur dapat dilakukan kapanpun, apabila kapuk pada kasur yang ada di rumah dirasa sudah mengeras dan kotor kasur tersebut dapat dijemur hari itu juga. Akan tetapi, jika orang luar Desa Kemiren ingin melihat kasur merah hitam dengan ukuran yang bermacam-macam yang dijemur secara serentak, maka harus mengetahui jadwal dari acara bersih desa di Kemiren. Karena tradisi Mepe kasur hanya dilakukan sebagai simbol pembersihan diri selama setahun yang diadakan juga setahun sekali. 


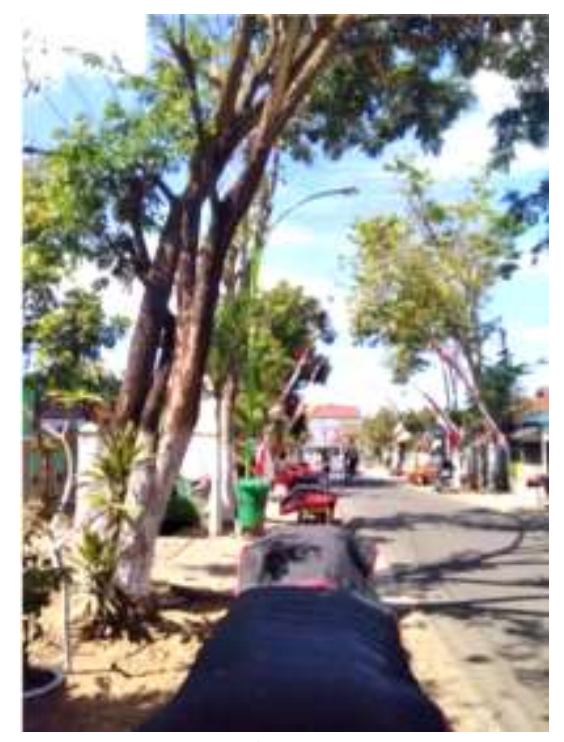

Gambar 1.

Kasur Merah Hitam yang Sedang Dijemur Serentak di depan Rumah Masing-Masing Warga

Upaya dari masyarakat Desa Kemiren dalam mempertahankan tradisi Mepe kasur adalah dengan dilombakannya acara tersebut. Lomba dimulai sejak pagi hari ketika kasur merah hitam dijemur, kriteria dan penilaian dari lomba ini berbagai macam seperti kekompakan antar RT dalam menjemur kasur, kondisi kasur, dan gembil yang dimiliki. Awalnya hanya gembilnya yang menjadi bahan penilaian, akan tetapi semakin tahun sangat jarang ditemukan gembil yang jumlahnya 5 dan 7 serta kasur yang masih dalam bentuk utuh lengkap dengan koin sen, sehingga pemenangnya pun hanya orang itu-itu saja. Oleh karena itu kriteria penilaian diubah untuk memberikan kesempatan kepada warga yang lainnya untuk dapat menang. Suku Bangsa Osing tidak mempermasalahkan mengenai peningkatan wisatawan yang memiliki kasur merah hitam mereka justru bangga budayanya dikenal dan diminati orang luar Desa Kemiren. Sebab masyarakat Desa Kemiren percaya suatu budaya akan tetap memiliki ciri khas masing-masing, karena secara tidak langsung mindset terhadap keunikan tiap budaya di masyarakat akan terbentuk dengan sendirinya seperti kasur merah hitam yang telah menjadi ciri khas dari Suku Bangsa Osing di Desa Kemiren.

Upaya lainnya untuk mempertahankan tradisi Mepe kasur adalah dari para orang tua di Desa Kemiren. Mereka memperkenalkan budaya mereka sejak dini kepada anaknya dengan cara membiasakan anak mereka tidur di kasur merah hitam bahkan ada juga orang tua yang membuatkan anak mereka kasur merah hitam berukuran mini, agar nantinya mereka merasa ada yang kurang jika tidak memiliki dan tidur di kasur merah hitam. Karena dengan dikenalkannya budaya sejak kecil akan menjadi sebuah kebiasaan untuk anak itu sendiri dan secara tidak langsung tindakan tersebut dapat tetap membuat kasur merah hitam lestari bertahan. Kemudian cara masyarakat Desa Kemiren tetap mempertahankan kasur merah hitam dapat dilakukan dengan mereka yang menggunakan kasur tersebut di homestay mereka. Mereka seakan bangga dengan ciri khas mereka dan ingin menunjukkan pada setiap wisatawan bahwa kasur merah hitam tidak kalah nyaman daripada kasur springbed. 


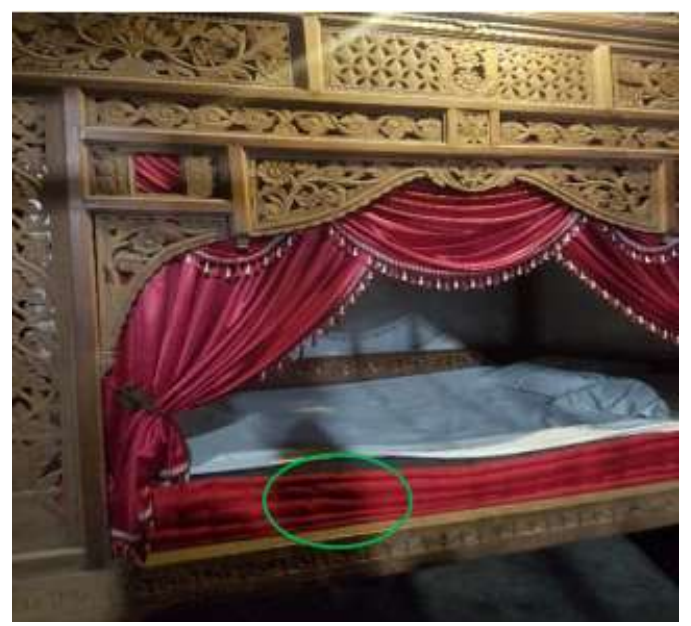

Gambar 2.

Kasur Merah Hitam dengan Gembil 5

Makna yang terkandung dalam tradisi Mepe kasur dan kasur merah hitam ada lima (5). Pertama yakni warna merah pada kasur melambangkan keberanian bagi seorang gadis dan suaminya dalam memulai hidup baru. Kedua adalah warna Hitam sebagai simbol kelanggengan atau pengharapan akan kehidupan pernikahan yang bertahan hingga masa tua. Ketiga yakni jumlah gembil di kasur, kasur merah hitam memiliki jumlah gembil (lipatan pada sisi kasur), gembil tersebut berjumlah kelipatan ganjil yaitu dimulai dari 3, 5, dan 7. Dalam Suku Osing di Kemiren, jumlah gembil menandakan status sosial seseorang dalam masyarakat dahulu hingga saat ini, sebab jumlah gembil itu dipakai pembuat sebagai tolak ukur harga dari Kasur Merah Hitam itu. Keempat adalah terkait dengan uang koin sen yang dijahit oleh pembuat kasur pada salah satu sisi Kasur. Koin tersebut bermakna sebagai kegigihan bagi pasangan baru suami istri dalam mencari nafkah untuk memenuhi kebutuhan hidup. Koin sen yang digunakan berwarna keemasan memiliki lubang di bagian tengahnya. Pada bagian depan koin sen terdiri dari nominal uang tersebut, gambar padi dan keterangan tahun pembuatan uang tersebut. Sementara bagian belakang dari uang sen didominasi dengan aksara Jawa dan huruf Arab. Makna yang kelima merupakan keterkaitan Tradisi Mepe Kasur dengan Desa Kemiren, tradisi tersebut dilakukan setiap Bulan Haji dan pada saat tradisi tersebut diadakan, Suku Bangsa Osing di Desa Kemiren menjemur kasur Merah Hitam tersebut sepajang hari. Hal tersebut bermakna untuk membersihkan diri dari hal hal negatif yang ada di dalam rumah. 


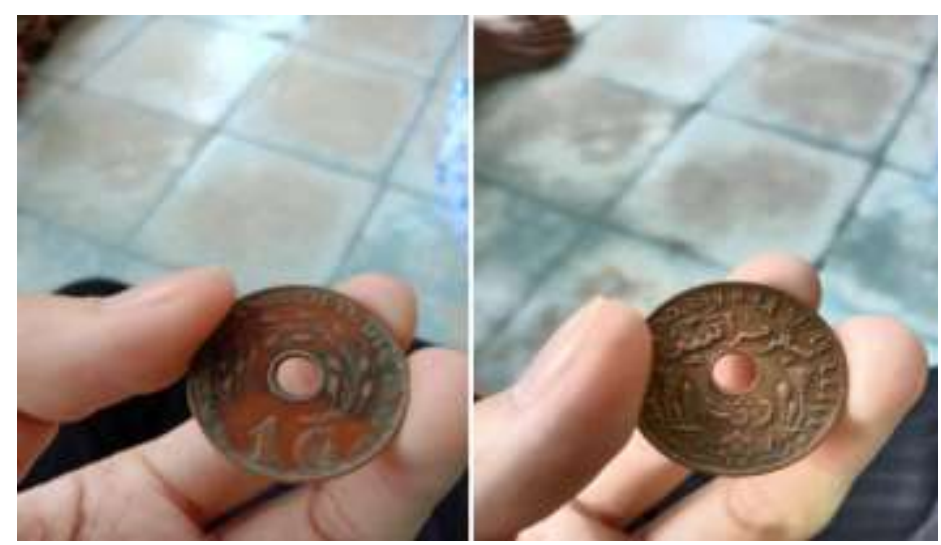

Gambar 3.

Dua sisi Koin Sen

Tradisi Mepe kasur termasuk pada ketiga tipe makna yang dijelaskan oleh BrodBreck (dalam Ananda: 2017: 10). Jika dianalisis menggunakan tipe makna BrodBreck dapat dijelaskan bahwa pada tipe 1 yaitu makna referensial tradisi Mepe kasur memang merupakan suatu ide dan pemikiran yang lahir dari masyarakat di Desa Kemiren sejak dahulu yang awalnya diwujudkan dalam bentuk kasur merah hitam. Akhirnya pada tahun 2009 muncul istilah tradisi Mepe kasur karena hasil musyawarah masyarakat Desa Kemiren. Kemudian tipe makna yang kedua yaitu arti dari istilah itu, jika istilah "Mepe" tidak disandingkan dengan kasur maka maknanya akan berubah dan cenderung biasa saja atau bahkan tidak memiliki makna, contohnya seperti mepe iwak, mepe klambi (baju). Tipe makna yang ketiga yaitu intensional yaitu lambang yang digunakan pada tradisi mepe kasur adalah kasur, mungkin masyarakat pada umumnya juga menjemur kasur seperti biasa saja dan menganggap kasur sebagai tempat tidur biasa, tetapi berbeda dengan Suku Bangsa Osing Di Desa Kemiren, selain sebagai tempat tidur mereka memiliki pandangan lain dan mengartikan kasur khususnya kasur merah hitam memiliki makna yang mereka percaya.

Sejak kemunculannya pada tahun 2009 tradisi Mepe kasur telah memberikan beberapa dampak bagi masyarakat di Desa Kemiren mulai dari dampak positif hingga negatif. Dampak positif yaitu berupa peningkatan pendapatan masyarakat Kemiren terutama pembuat kasur merah hitam. Selain itu antusiasme dari masyarakat luar desa hingga luar Banyuwangi yang ingin belajar kebudayaan dan tradisi yang ada di Kemiren membuat masyarakat Kemiren semakin kreatif dengan membuka usaha-usaha baru, seperti rumah makan dan kafé yang menyediakan makanan khas Kemiren yang berkonsep etnik. Dampak lainnya dari tradisi mepe kasur yang telah diketahui oleh masyarakat luas adalah peluang usaha bagi Suku Bangsa Osing di Desa Kemiren berupa jumlah pemesan kasur merah hitam yang semakin meningkat. Masyarakat Desa Kemiren menjadikan kasur merah hitam di homestay mereka dengan kata lain adanya peningkatan pendapatan bagi pemilik homestay di Desa Kemiren dinilai sebagai dampak positif. Peningkatan pendapatan masyarakat Desa Kemiren tidak terlepas dari liputan media yang datang ketika bersih desa dan tradisi mepe kasur dilaksanakan.

Selain memberi dampak positif media juga memberikan dampak negative yaitu berupa semakin hilangnya ruang privasi yang dimiliki Suku Bangsa Osing di Desa Kemiren akibat peningkatan kunjungan orang-orang dari luar desa hingga luar kota. Sehingga menimbulkan dampak negatif lainnya yaitu beberapa masyarakat yang belum biasa desanya yang dulunya sepi kini didatangi banyak orang hampir setiap hari. Mereka merasa terganggu akibat belum terbiasa dengan keadaan 
di desanya kini. Akan tetapi hanya beberapa saja warga masyarakat yang seperti itu. Dampak negatif lainnya yang ditimbulkan dari segi pelestarian budaya tradisi ini yaitu hilangnya makna kasur merah hitam yang selama ini dipahami masyarakat. Hal itu merupakan dampak negative dijual nya kasur merah hitam sebagai barang komersial dan telah menjadi konsumsi publik. Ironisnya hal tersebut hanya disadari oleh sebagian warga masyarakat dan bahkan ada yang tidak menyadarinya. Sebagian warga masyarakat menganggap hal tersebut bukan sebagai hal prioritas.

\section{Simpulan}

Tradisi Mepe kasur di Desa Kemiren hingga saat ini masih tetap lestari dan dilaksanakan sebab Suku Osing di Kemiren percaya dalam tradisi Mepe kasur bukanlah sebatas menjemur kasur seperti biasa dan menggunakan sembarang kasur. Tetapi dalam tradisi tersebut kasur yang digunakan memiliki makna tersendiri bagi mereka. Makna yang meliputi warna dari kasur, properti yang digunakan di kasur merah hitam yang tak lain adalah koin sen, lipatan yang ada pada kasur merah hitam, dan alasan mengapa kasur tersebut dijemur. Seluruhnya memiliki nilai dan pemaknaan yang berbeda.

Generasi sebelumnya secara tidak langsung telah mengajarkan dan menyisipkan nilai-nilai penting yang ada dalam aktivitas sehari-hari dari hal yang sangat sederhana dan terlihat sepele. Akan tetapi, nilai yang terkandung dalamnya merupakan bentuk dari rasa syukur generasi sebelumnya kepada Sang Pencipta karena telah memberi kesehatan serta keselamatan selama mereka hidup. Oleh karena itu tradisi Mepe kasur diwariskan dan dapat tetap bertahan hingga saat ini. Studi selanjutnya penting dilakukan penelitian tentang seberapa besar peningkatan pendapatan yang berhasil meningkatkan kehidupan sosial ekonomi dan budaya warga Desa Kemiren.

\section{Daftar Pustaka}

Ananda, R. A. (2017) Pemaknaan Pesan Video Sketsa Pada Instagram @ Alfysaga Di Kalangan Video Creator Sebagai Bentuk Fenomena Kehidupan Anak Muda (Studi Resepsi pada Anggota Komunitas Malang Creator). Tesis. Universitas Muhammadiyah Malang.

Fuadhiyah, U. (2011) Simbol Dan Makna Kebangsaan Dalam Lirik Lagu Dolanan di Jawa Tengah Dan Implemensasinya Dalam Dunia Pendidikan. Lingua, 7 (1): 15-26.

Geertz, C. (1992) Tafsir Kebudayaan. Yogyakarta: Kanisius.

Spradley, J. P. (1997) Metode Etnografi.Yogyakarta: Tiara Wacana.

Syam, L. I. S. (2017) Pergeseran Makna Tradisi Kalomba Bagi Komunitas Kajang Dalam Tanah Toa Di Bulukumba. Skripsi. Makassar: Universitas Hassanudin.

Wilwatikta, W. Z. A. (2019) Tradisi Rewangan: Kajian Etno-Cooking Dan Perubahan Makna Rewangan Pada Masyarakat Kota Bandar Lampung. Skripsi. Universitas Lampung.

Winoto, Y. (2018) Makna "Pencemaran Lingkungan" Bagi Para Penambang Emas Tradisional. Commed, 3 (1): 52-63. https://doi.org/10.33884/commed.v3i1.605. 